\title{
Civil court staff in Kenya: working conditions and legal training for an effective procedure
}

\author{
George Kashindi and Hannah Wamuyu*
}

\begin{abstract}
Courts are very important because their pronouncements become part of the law in light of the provisions of section 3 of the Judicature Act, 1967. Therefore, the process of making judicial determinations on issues before courts must be treated with the necessary efficiency. Delivery of justice involves both judicial and administrative work. That is to say, for expediency in the administration of justice to be met, there is a need for other administrative functions which cannot be done by the judges. Therefore, the role of judicial staff in case management is critical in the functioning of the judiciary. Though the Judiciary has come up with different initiatives to build capacity for judicial staff, the initiatives including the approval of the Judiciary Human Resources Policies and Procedure Manual 2014, continue to exist amidst serious training and human practice challenges on motivation, security, and adequacy of facilities. This paper discusses the initiatives that the Judiciary has put in place to attract and maintain the best human resource capital. It proposes that strategic investment in information and communication technology will help overcome the challenges as the Judiciary moves towards its identified strategic direction of quality judicial service.
\end{abstract}

\section{A. INTRODUCTION}

The Kenyan judiciary struggles with the challenge of backlog of cases. ${ }^{1}$ In 2014, it was reported that Judiciary estimated that the cases per judicial officer is $250 .^{2}$ Two years later, the caseload data according to the State of the Judiciary Report shows that the there is a huge caseload in civil cases despite a record of increased efficiency with the magistrate's courts being the busiest in terms of case inflows at $69 \% .^{3}$ This continues to complicate the

* George Kashindi, LL.B, LL.M (Financial Services Law) (University of Nairobi), Advocate High Court of Kenya. Email: kashindi@mmkadv.com.

Hannah Wamuyu, LL.B, LL.M (University of Dar es Salaam), PhD (Environment Law) Candidate (University of Nairobi), Advocate High Court of Kenya, Lecturer, School of Law (Jomo Kenyatta University of Agriculture and Technology (JKUAT).Email: wamuyuhanna@gmail.com.

1 Judiciary, Case Audit and Institutional Capacity Survey, 2014, Volume 1, 41.

2 Ibid. See also The Judiciary, Strategic Plan, 2014-2018, 9.

3 Judiciary, State of the Judiciary and Administration of Justice Annual Report. 2016-2017, 23. The records are 388, 644, 350, 345 and 347, 981 civil case backlog in all the courts in 2014/2015, 2015/2016 and 2016/2017 financial years respectively. 
Judicial Performance Improvement Project. ${ }^{4}$ It is against this backdrop that the Judiciary has established mechanisms for speedy disposal of cases. ${ }^{5}$ This further supports the guarantee of access to justice as a guaranteed right under the Bill of Rights. ${ }^{6}$ One of the major aspects of the right is the reduction of the caseloads and effective case management. Recent research findings have also underscored that unlike hiring of additional judges and magistrates, the hiring of additional judicial staff is an effective strategy for efficient reduction of the caseload in the civil courts. ${ }^{7}$ Thus, the judicial staff is an integral part of the justice system. However, the integration can only be effective if the staff numbers are optimized along with the right skills, competence and training among other motivating human resource practices. The progressive optimization strategies can be rejuvenated by certain reforms in the judiciary towards achieving the strategic plan of becoming an enabler of access to justice.

\section{B. CIVIL COURTS IN KENYA}

Civil courts adjudicate on matters between the citizens in order to determine the extent of liability of one against the other. Kenyan legal system does not place any dichotomy of criminal courts and civil courts. Courts have the capacity to hear both matters at different times. This is very common with the magistrate's courts. Accordingly, the judicial staffs are expected to work hand in hand with the judges in order to administer justice in all nature of cases. Only judges in the superior courts can be stationed with specific court divisions. The Kenyan court system is based on the British model of courts. However, this has been further modified with a series of legal reforms that have culminated into the Constitution of Kenya. Apart from the constitutional basis, civil courts are also created by the statutes that prescribe for the better carrying out of the functions of reach civil court.

Judiciary is one of the three arms of the National Government with the power to exercise the sovereignty of the people. ${ }^{8}$ The sovereignty of the people of Kenya is paramount and is the basis upon which the Constitution of Kenya is premised. ${ }^{9}$ The Judiciary is established by the Constitution and derives power from the people. ${ }^{10}$ The fact that the judiciary and the courts are a creation of the Constitution has certain legal ramifications. First, the judiciary is enjoined to promote such aspirations of Kenyans as human rights, equality, freedom, democracy, social justice. Further, the judiciary is enjoined to uphold the national

4 Judiciary, Judicial Performance Improvement Project (JPIP) Progress Report Jan-May 2018.

5 Judiciary, note 4, 11.

6 Ibid 6. The judiciary's philosophy is based on the Constitution of Kenya.

7 Aldamir Gomes, Tomas Aquino, and Luiz Akutsu, Relationship between Judicial Staff and Court Performance: Evidence from Brazilian State Courts, International Journal of Court Administration, Volume 8 Issue 12018.

8 Article 1(3)(c). The County Government that is created under Chapter 11 of the Constitution of Kenya, 2010 does not have the judicial arm.

9 Constitution of Kenya, 2010, article 1(1).

10 Ibid, Article 159(1). 
values and principles of governance such as human dignity, inclusiveness, protection of the marginalized. Judiciary is also a key promoter of access to justice to all persons and to charge only reasonable fees that do not impede access to justice. ${ }^{11}$ Notably, the administration of justice in the civil courts falls within the purview of an administrative action and should ensure that its quality of service meets the criteria of being procedurally fair, efficient, expeditious and reasonable. ${ }^{12}$

Further, civil courts are obliged to follow the principles that: justice must be done to all irrespective of status; justice must not be delayed, alternative forms of dispute resolution should be promoted, and that justice must be done without any undue regard to a procedural technicality. ${ }^{13}$ The principles are further augmented by the principle of the independence of the judiciary. ${ }^{14}$ The structure and the hierarchy of civil court system in Kenya can be listed in the descending order as: Supreme Court, Court of Appeal, High Court and Court of similar status and Magistrates Courts and Kadhis' Court. The special courts with similar status as the High Court of Kenya are the Employment and Labour Relations Court and the Environment and Land Court ${ }^{15}$ The Supreme Court hears appeals from the Court of Appeal and enjoys exclusive jurisdiction to hear disputes related to the election to the office of the President. The Court of Appeal with an appellate jurisdiction to hear civil appeals from the High Court or any other Court as may be prescribed by an Act of Parliament. ${ }^{16}$ The High Court hears appeals from the subordinate courts and it also enjoys the unlimited original jurisdiction to hear all civil matters. ${ }^{17}$

Kadhis' courts hear and determine civil matters between persons professing Muslim faith and which relates to their personal status be it marriage, divorce, or inheritance. ${ }^{18}$ The Magistrates Courts Act, ${ }^{19}$ provides for various categories of Magistrates Court and prescribes their jurisdiction. The magistrate's courts established under the Act are under auspices of the Chief Magistrate, Senior Principal Magistrate, Principal Magistrate, Senior Resident Magistrate, Resident Magistrate with jurisdiction limit on the value of subject matter worth twenty million shillings, fifteen million shillings, ten million shillings, seven million shillings, and five million shillings respectively. ${ }^{20}$ The Small Claims Court has been established but is not operational. ${ }^{21}$ By the year 2015, the Supreme Court had seven judges. The

12 Ibid, Article 47.

13 Ibid, Article 159(2).

14 Ibid, Article 160.

15 Ibid, Article 162(2).

16 Ibid, Article 164.

17 Ibid, Article 165.

18 Ibid, Article 170.

19 Magistrates Court Act, (Act Number 26 of 2015).

20 Ibid section 7(1).

21 Judiciary, note 4, 18. 
Court of Appeal has 25 judges with 3 having already retired. Currently, the Court of Appeal has six registries one in Nairobi, Mombasa, Nyeri, Kisumu, Malindi, and Eldoret. There were 109 High Court judges in 20 stations in Kenya including the courts with the similar status as the High Court. There were also 473 magistrates and 35 kadhis who are in charge of various stations. ${ }^{22}$ These numbers have not changed significantly.

\section{CIVIL COURT STAFF IN KENYA}

Judicial staff is any person who is employed in the judiciary but lacks the power to make a judicial decision. ${ }^{23}$ These employees can be retained on a permanent and pensionable, contract or casual basis. ${ }^{24}$ Judicial staff is an integral part of the judicial system. The staff's capacity can only be manifest if they possess the technical and administrative competence and uphold quality service and positive values. ${ }^{25}$ There are various offices and persons that help the court staff in their day to day activities and have been discussed below:

\section{LEGAL RESEARCHERS}

The Judicial Service Act creates the position of a legal researcher. ${ }^{26}$ The functions of the legal researchers are to aid the judges with their day to day research work. This role is integral because the decisions of judges and magistrates are guided by the stare decisis principle.

\section{CHIEF REGISTRAR}

A Chief Registrar is the chief administrator and the accounting officer of the Judiciary. ${ }^{27}$ The office of the Chief Registrar accounts for all monies and ensure proper books of and records of the Judicial Service Commission and judiciary are kept; ${ }^{28}$ conducts the management of the day-to-day operations including the administration of human resources; efficient organization of the staff and the overall planning, preparation and implementation of budgets. Other functions are to prepare proposals for the administrative issues, ensure all procurements as well as maintenance of the judicial facilities and develop co-operation with other institutions. ${ }^{29}$

22 Ibid, 5-6.

23 Section 2 of the Judicial Service Act (JSA) (Act Number 1 of 2011).

24 Judiciary, Human Resources Policies and Procedure Manual. 2014, 14.

25 Ibid clause 4.

26 JSA, $\mathrm{s} 7$.

27 Article 161(2)(c).

28 See note $24,39$.

29 Ibid section 8(1). 


\section{DIRECTORS}

The Judiciary has different directorates responsible for human resources and administration, finance, public affairs and communication, performance management, supply chain management, and accounting. The role of the directors in the judicial system is what a pedal is to a bicycle. Even with the right drivers and well-oiled wheels, the bicycle cannot move a step unless the pedals are put to action.

\section{DEPUTY CHIEF REGISTRARS/ASSISTANT REGISTRARS}

The Chief Registrar is assisted by Deputy Registrars or Assistant Registrars for the performance of the judicial service. ${ }^{30}$ The functions of the Deputy Registrars are to: assist the Chief Registrar in the administration and management functions; and be responsible for each superior court. ${ }^{31}$

\section{NATIONAL COUNCIL ON ADMINISTRATION OF JUSTICE}

The Council is comprised of most of the non-judicial officers from the police, prosecution, probation and the cabinet. Others are non-governmental organizations and the advocate's professional body; Law Society of Kenya, representatives from the National Police Service, and the private sector. ${ }^{32}$ The Council meets once in every three months ${ }^{33}$ and is mandated to prepare annual reports and submit to the Cabinet Secretary responsible for judiciary for onward transmission to the National Assembly for consideration. ${ }^{34}$ Its function is to formulate policies relating to the administration of justice, facilitate the establishment of court user committees, and to mobilize resources for the efficient administration of justice. ${ }^{35}$

\section{COURT CLERKS}

The court clerks are officers who are attached to particular court stations or judges to assist the judicial officers in the day-to-day running of the court processes. For expediency, in Kenya the clerks can work in the registries, chambers or at the entrance of the courts. They perform duties such as archiving, preparing, making and updating cause lists to offer guidance to the litigants in civil cases on case numbers, dates, presiding judges and magistrates and the time allocation. The clerks also undertake writing summons issued by courts to litigants or witnesses; making arrangements to ensure availability of files; and receiving and

30 Ibid section 10.

31 Ibid.

32 Ibid section 34(2).

33 Ibid section 36.

34 Ibid section 37.

35 Ibid section 35(2). 
filing court documents that are filed by litigants. Other duties are answering to any inquiries that the litigants may direct to the legal clerks; preparation of court processes for dispatch through the court process servers to the various litigants; ensuring the opening of files for new cases that are filed in the civil court registries; ${ }^{36}$ keeping a register of cases, retrieval of files and aiding in the interpretation of the languages in case of litigants who cannot understand the official language of the court.

\section{PROCESS SERVERS}

The Kenyan judiciary also employs persons who execute the processes such as orders of the court or other hearing notices that are given at the instance of the court. The process servers play an important role in the justice delivery through service of court processes and deponing an affidavit immediately after a service of process. They also give witness testimony in cases where a service of process is disputed and is usually common in cases of contempt of court for disobedience of orders, maintaining a register of all the court processes; and aiding the auctioneers in the actions for the purposes of execution of court orders.

\section{OFFICE OF THE OMBUDSMAN}

The Office of the Ombudsman is established under the Commission on Administrative Justice $\mathrm{Act}^{37}$ and is responsible for the enforcement of administrative justice for the judicial staff. ${ }^{38}$ Its key functions are to establish a proper complaint handling system, receive and investigate complaints from the public and litigants regarding the investigation of the judicial staff, consider and investigate allegations of misconduct of the judicial officers and staff, and conducting spot checks on the court stations. ${ }^{39}$

\section{SECRETARIES}

The personal secretaries and secretarial assistants aid the judicial officers at personal levels to arrange for their programmes and plans. They also type proceedings of the court.

\section{CIVIL COURT STAFF AND ADMINISTRATION OF JUSTICE}

Ideally, a legal system that places a judge with both administrative work and judicial authority is only doing so in total disregard for justice. One doubts whether there would be such an intended system anywhere in the world. Doubtless, this is not the situation in Kenya either. In fact, from the highlights of the various judicial staff, it is evident that for the judicial

36 See note 2, 39.

37 Commission on Administrative Justice Act (Act No. 23 of 2011).

38 Ibid.

39 Ibid 39. 
officers dispense justice, the assistance of Chief Registrar, the directorates under the Chief Registrar, legal researchers, process servers, court clerks, the office of the ombudsman and the National Council on the administration of justice comes in handy. The administrative role augments the exercise of judicial authority and to make justice not only to be done but also to be seen to be done. If the judicial service is to be a chain process, then without the links of the judicial staff in Kenya, the chain would be incomplete and unworthy of calling a justice system as justice would not be guaranteed in the end.

If the rationale that courts do not give orders in vain is anything to go by, then without the judicial staff, then there would be no need for any court to make any pronouncement in a civil suit because of lack of mechanisms for implementation. ${ }^{40}$ Therefore, though the work of the staff can be said to be secondary to the exercise of judicial authority, their role goes to the core of solving any administrative challenges such as giving necessary information for court users. Evidently, this is what gives the judges and magistrates time to devote to the very core function of exercising judicial activity. ${ }^{41}$ This way, the commitment to quality judicial service is affirmed. The division of labour therefore just complements the role of judicial officers. The role played by each of the players in the chain is what increases the productivity of the court because of the devotion of competence and skills in each area of delivery of justice.

\section{E. STAFF WORKING CONDITIONS}

The conducive working environment has a positive impact on the productivity of any staff member. ${ }^{42}$ Recent studies have shown that the working conditions in Judiciary are still low, albeit with certain improvements. ${ }^{43}$ The National Case Audit and Institutional Capacity Survey was done by the judiciary revealed that the judiciary offers inadequate facilities, being chambers and courtrooms at a percentage of $70 \% .{ }^{44}$ The inadequacies albeit in different percentages transcends to meeting rooms and working space, waiting for areas, libraries, and registries. ${ }^{45}$ The safety of most of the staff members is also at risk. For instance, most court stations do not have fire extinguishers and fire escape routes or stairs and those which have only a few are functioning. ${ }^{46}$ For the process servers, the safety risks are even higher due to the fact that they are likely to meet hostility when serving court processes.

41 Ibid.

42 Judiciary, note $1,39$.

43 Ibid 33.

44 Ibid.

45 Ibid.

46 Ibid 39. 
The Judiciary has worked on a Judiciary Human Policies and Procedures Manual which details most of the staff working conditions that affect the judicial staff. ${ }^{47}$ The Manual provides that all employees must be recruited through the office of the Chief Registrar after the due filling of the staffing needs by the different directorates or a vacancy duly brought to the attention of the JSC. ${ }^{48}$ The recruitment is competitive and involves shortlisting, interview and selection, the offer of employment, letter of acceptance and then a letter of appointment. By 2016 alone, the Judiciary recorded a total of 666 judicial staff. ${ }^{49}$

The judicial staff that are recruited must first meet the constitutional and statutory requirements which vary for each staff. The selection process is also done on merit as per the job descriptions granted in the public advertisement. ${ }^{50}$ Generally, the subsequent employment relationship is also governed by the Employment Act, 2007 which is the principal law on the employment matters in Kenya. The Manual also prescribes for the promotion of the staff. In essence, any member of staff can apply for the promotion through the head of its station. ${ }^{51}$ This automatically leads to an increase in the salary scale. The same applies to the upgrading of positions as well as acting appointments. In the financial year 106/2017 alone, there was a grand total of 294 promotions of judicial staff. ${ }^{52}$ The judicial staff is also amenable to transfers to be considered on merit with a member of staff entitled to a one month's notice and transfer allowance. ${ }^{53}$ This transfer almost comes as a guarantee because the maximum period for staying at a station is 3 years. The Judiciary also conducts performance management for its staff in order to determine the performance of the employees and the alignment to the annual work plan for every court station. ${ }^{54}$ The staff are expected to do their own personal evaluations. ${ }^{55}$

Judiciary also enforces discipline which binds all the judicial staff members. The disciplinary process is guided by principles of good reason and natural justice and hence not arbitrary. The procedure for handling misconducts, gross misconduct and grievance are robust and well laid down. There are, however, different procedures for a disciplinary process for misconduct and gross misconduct. Where a process leads to an interdiction, the employee is entitled to a half a salary and if it is a suspension, to an alimentary allowance. ${ }^{56}$ The Judiciary ensures an array of leaves ranging from annual leave, commutation of leave, maternity leave, paternity leave, sick leave, adoption leave, compassionate leave, leave of absence

47 Judiciary, Human Resources Policies and Procedure Manual, 2014, 10.

48 Ibid 15-16.

49 Judiciary, note 3, 129.

50 Ibid, note 47, 17.

51 Ibid, 23.

52 Judiciary, note 3, 136.

53 Ibid, 26.

54 Ibid, 34.

55 Ibid.

56 Ibid, 43. 
to terminal leave for those who are entitled to them. Others are paid study leave, examination leave, sabbatical leave, special leave for sportsmen. The staff must however first apply for the leave. ${ }^{57}$ All gazetted public holidays are also recognized by the Judiciary and unless exigencies of duties demand, the employees are entitled to be granted days off duty. ${ }^{58}$

The Judiciary has also placed avenues for career management, career planning ${ }^{59}$ as well as management of talents. ${ }^{60}$ Further, the judicial staffs are entitled to remuneration and benefits based on the various job groups and description less the statutory deductions. The staff is also entitled to salary advances payable within 12 months. Further, and based on the on grade and responsibility, the judicial staff is entitled to a house, acting, special duty, hardship, responsibility, commuter and leave allowance, and a non-practicing allowance. Others are entertainment, alimentary, trainers, risk, retreat, dust coat, security and airtime allowances for those who are entitled. ${ }^{61}$ Communications with other arms of the government are limited and can only be channelled through the Chief Justice. Internally, the way communication is encouraged for the staff to enable inclusivity. This can be done through brochures, circular, meetings, letters, memoranda, reports, notice boards among others. Further, only authorized persons are allowed access to official records ${ }^{62}$ and the staff is prohibited from irresponsible use of the social media. ${ }^{63}$

The judicial staff members are also guaranteed occupational health and safety working environment in accordance with the Occupational Health and Safety Act, 2007 to minimize the exposure to occupational accidents for the judicial staff. ${ }^{64}$ The policy on separation with the employees through retirement and other means is also well provided for. The retirement age for the staff of the JSC is sixty being the retirement age for the public officers. ${ }^{65}$ The members of staff for the commission may, however, elect to retire at 55. ${ }^{66}$ Employees with ten years of service are entitled to terminal benefits. ${ }^{67}$ The judiciary does not however guarantee housing for the judicial staff. Once such a chance avails itself, the staff should be responsible and can be surcharged for wanton damage. ${ }^{68}$ The staff is also guaranteed access to vehicles. Any travel by air for official duty must be approved by the Chief Registrar. ${ }^{69}$

57 Ibid, 49.

58 Ibid, 56.

59 Ibid, 63.

60 Ibid, 64.

61 Judiciary, note 47, 73-84.

62 Ibid, 94.

63 Ibid, 96.

64 Ibid, 100.

65 Judicial Service Act, section 25(1).

66 Ibid section 25(2).

67 Judiciary, Human Resources Policies and Procedure Manual. 2014, 110.

68 Ibid, 115.

69 Ibid, 115. 
When a staff member retires such transport to his or her home is provided. The vehicles must only be driven by official drivers and not any other member of staff.

Lastly, the judiciary ensures employee welfare through a support mechanism for a person suffering from HIV/AIDs, offering guidance and counselling, prohibition of drug abuse, loan and purchase schemes for vehicles and houses. ${ }^{70}$ Further to this, judiciary has planned for initiatives for the medical insurance scheme, work injury benefits and creation of a social club and other recreational facilities. ${ }^{71}$ All these prescriptions help motivate and increase the productivity of the judicial staff hence ensuring speedy resolution of cases as envisaged in the Judiciary Strategic Plan. ${ }^{72}$

\section{F. STAFF LEGAL TRAINING}

National Case Audit \& Institutional Capacity Survey finding concluded that acceptable court personnel is necessary to ensure that the judicial determination is efficient are timely. ${ }^{73}$ The finding places premium on the word 'acceptable.' This means that the duty of the judiciary is not only to procure the services of any staff but also to ensure judicial staff is qualified and acceptable. One of the keys to acceptability is the proper training. The Judiciary has put in strategies to circumvent the current issues on institutional capacity. The Judiciary Human Resources Manual prescribes for induction of its staff. ${ }^{74}$ The Manual also recognizes a training plan which is initiated through a training needs assessment and annual training objections. The Judiciary ensures that the training is tied to the gap in the performance and that the training is administered by accredited persons ${ }^{75}$ All these trainings target employee development as well as succession management. The training is coordinated by the Chief Registrar in collaboration with the Judicial Training Institute. In order to reap from training, the Judiciary provides for training bonds and caters for a subscription to professional bodies as well as conducting and monitoring and evaluation of the training for chances of improvement. ${ }^{76}$ For example, in the 2016/2017 financial year, the number of trainings that were done was 1568 covering areas like supervisory skills, pre-retirement, and induction. ${ }^{77}$ Despite these efforts, the current state of capacity is still wanting. The existing training is not properly coordinated and planned to impart the necessary skills. A key informant working as a Senior Magistrate was of the view that the training was not adequate. This is because the training was not up to date in terms of keeping up with the

70 Ibid, 131.

71 Ibid, 131-133.

72 Judiciary, note 2, 11.

73 Judiciary, note 1.

74 Judiciary, note 47, 22.

75 The person must be accredited by Nations Industrial Training Authority (NITA).

76 Judiciary, note 47, 63-64.

77 Judiciary, note 3, 134. 
changes in law. Further, a few of the judicial staff, those who work as clerks, opined that the training is more concentrated with the stations located in big towns and cities. This concern was also registered by the magistrates. The ones who worked in urban areas are more privileged to access training.

The National Case Audit and Institutional Capacity Survey shows that up to 10 percent of all court stations had less than five (5) judicial staff while 11 percent had between 5 and 10 judicial staff. ${ }^{78}$ Forty-seven (47) percent of the court stations had between 10 to 20 judicial staff compared to 35 percent of the court stations with more than 20 judicial staff. This shows that in certain instances, the number of judicial staff was below the average of 12 judicial staff per count registry. ${ }^{79}$ The survey also revealed that in some of the instances, the support staff was deployed to serve the registry in order to fit in the existing ration of 1 judicial officer to 6 judicial staff. ${ }^{80}$ This has happened despite the fact that the support staff lacks the necessary skills to undertake the clerical work among others. ${ }^{81}$

The initiatives for creating conducive working condition for judicial staff under Judiciary Human Policies and Procedures Manual can thus be properly implemented if Kenya follows with a proper structure of training and investment in facilities and personnel. Kenya has already shown the good signs of commitment to capacity development through the establishment of Judicial Training Institute. The main objective of the Institute is to meet the research, training and capacity development needs for the staff of the judiciary. Despite the existence of the Institute, there continues to be reported a limited number of ad hoc and external seminars and training. ${ }^{82} \mathrm{An}$ improvement on the training strategy will enable the achievement of the strategic plan of guaranteeing fair and efficient resolution of civil disputes and access to justice ${ }^{83}$ and the mission of being a fair, timely, accountable and accessible administrator of justice and the core value of diligence. ${ }^{84}$

\section{G. CHALlengeS}

The judiciary has progressively improved the working conditions of the court staff. The training aspects have also improved. However, there are a few challenges that hamper effective working by the judicial staff. Sometimes the judicial staff and the officers have suffered judicial depression which in turn negatively affects work delivery. ${ }^{85}$ The systems are such that the judicial staff is expected to solve problems that may affect their performance.

79

80 Ibid

81 Ibid.

82 Ibid.

83 Judiciary, notes 2 \& 24.

84 Ibid, 6.

85 This information was shared by a key informant who has worked as a magistrate for over 5 years. 
There are no established formal welfare systems which can be of help where one suffers issues such as death in the family. Further the system is such that a judicial officer is unable to interact hence isolation and loneliness may set in. There are no debriefing mechanisms hence some officers are affected by some mental health related sicknesses. ${ }^{86}$ A key informant who has worked as a clerk for over 5 years stated that one of the challenges that clerks face is what he called "judicial harassment". This is where clerks are made to be answerable for missing court files and documents and which may lead to dismissals. Most of the times it would not be their fault for such loss. The harassment would also originate from the litigants as clerks most of the times would be the first point of contact. They would be made answerable for even failure of the courts to hold scheduled hearings.

The Judiciary staffs continue to engage in tedious work because of lack of an integrated information communication technology system. Further, there is also corruption as a challenge. ${ }^{87}$ This would create situations of missing files and crucial exhibits. This adversely affects the performance as hearings and court procedures are interfered with.

Transfers have also presented major challenge as most of the times it disorganises the officers' way of life. This would act as a factor of demotivation and would eventually negatively affect performance. ${ }^{88}$

\section{H. CONCLUSION AND WAY FORWARD}

The integrated work of judicial officers and acceptable judicial staff can guarantee both substantive and procedural justice by a reduction in disposition time. Therefore, courts should invest in the libraries and ensure that the assistants and the staff visit the libraries to acquaint themselves with the latest developments in the law. This will aid in circumventing the challenge of resources for financing the training sessions of the judicial staff.

Kenyan courts should be more committed to the integration of their services by investing in ICT services through an integrated court management system. The Courts should start by rewarding innovations in order to reduce the disposition times and investing in ICT solutions in order to have an Integrated Court Management System over and above the provision for access of cause lists from the online websites.

Although there are increasing steps towards review of the available staff, the review has not been optimized with regards to matching their skills and work. This should go in hand with the increase in the judicial staff in areas with less than average staff in order to complement the work of judicial officers. Kenyan Judiciary should effectively implement its training on the core and regulated courses and to preventing the inefficiencies of holding external seminars and training despite it having an institute for judicial training. Further, the

86 Ibid.

87 Judiciary, note 2.

88 Jack Murima, LSK President laments frequent Transfer of Judges and Magistrates' 27 May 2018 https://www.standardmedia.co.ke/article/2001281961/lsk-president-laments-frequent-transfer-of-ju dges-and-magistrates $>$ (accessed 23 January 2019). 
Council on Administration of Justice should continue its lobbying for resources and funding by donors and non-donors alike in order to satisfy the financial resource requirement. Lastly, the Small Claims Court should be made operational with its own staff to reduce case backlog that arises from overstretching of the staff.

\section{BIBLIOGRAPHY}

The Constitution of Kenya, 2010

The Judicial Service Act (Act No.1 of 2011)

The Magistrates Courts Act (Act No. 26 of 2015)

Aldamir Gomes, Tomas Aquino, and Luiz Akutsu, Relationship between Judicial Staff and Court Performance: Evidence from Brazilian State Courts, 2018, International Journal of Court Administration, Volume 8 Issue 1.

Bhattarai \& Uprety, Institutional Framework for Legal and Judicial Training in South Asia. Law and Development Working Paper series, no. 2.

Judiciary, Case Audit Report and Institutional Capacity Survey 2014, Volume 1.

Judiciary, Human Resources Policies and Procedure Manual, 2014.

Judiciary, Judicial Performance Improvement Project (JPIP) Progress Report Jan-May 2018.

Judiciary, State of the Judiciary and Administration of Justice. 2016-2017, Annual Report.

The Judiciary, Strategic Plan. 2014-2018. 